\title{
FACTORS SHAPING COMPETITIVENESS OF THE REGION
}

Regions are competing between themselves for the highest position in the country. Achieving and maintaining this position is associated with benefits such as attracting investors, the growth of entrepreneurship living in the region or commune, improvement of housing conditions, local enrichment, lower unemployment, lower social spending and the development of the real estate market.

The inventors of the region potential are: entrepreneurs, groups connecting various environments (clusters, associations), Special Economic Zones, knowledge, innovation, and the living conditions of citizens.

Regions compete with each other by using monuments, attracting investors and investing funds. The main factors of territorial competition are associated with local resources. The most common and most general division of territorial competitiveness factors are classified into internal and external. External factors include national and global environment, social, economic and spacious politics of the state and other organizations. Internal factors are local opportunities and development needs. They are in the local coordinate system and depend on local resources (quantity and quality of education inhabitants of commune or region, natural resources in the region, the policy of the region - pro-health, pro-family and pro-environmental, infrastructure), their accessibility, quality and efficiency of their use.

The aim of this article is to discuss about creators of region potential (mainly entrepreneurs, clusters, associations, Special Economic Zones), and the relationships between them.

Key words: clusters, local associations, special economic zones, the development of the region

\section{Introduction}

Region is contractually separated area, relatively homogeneously differed from neighboring areas of natural features or acquired historically. Regions are organized and artificial creations, which by coordinating the activities and relationships of its members and resources perform planned transactions with

Katarzyna Szymańska, PhD, Faculty of Engineering and Economics, Poland, e-mail: katarzyna.szymanska@pwszciechanow.edu.pl 
the environment, realizing goals of (administrative or economic) founders and participants (Jabłoński and Jabłoński, 2012, p. 11).

Regions want to achieve a high position in the country. Achieving and maintaining a high position is associated with numerous benefits: attracting investors, increase of entrepreneurship residency in the region or commune population, improvement of housing conditions, local enrichment, lower unemployment, lower social spending and the development of the real estate market - its activity and increase in value. Local governments have been equipped with various instruments that create the conditions for local development, such as the ability to develop programs and strategies, activity in the sphere of budget, regulatory powers in the area of tax law and spatial development, administrative decision, contracting and the ability to benefit from aid funds: domestic and foreign. Local development strategies are result of rationalization deployment of the forces, resources, and responsibilities of local authorities for shaping and stimulating development.

Regions compete for monuments, investors, financial resources and territory. The main factors of territorial competition are result the offer local resources that affect location choices of companies. The most common and most general division of territorial competitiveness factors are classified into internal and external.

External factors are politics, national and global environment of the region, linked to the social, economic and spatial policy state and other organizations.

The internal factors include all the local opportunities and development needs (Jewtuchowicz, 2005, p. 30) These factors are present in the local coordinate system and depend on local resources (quantity and quality of education inhabitants of the commune or region, natural resources in the region, regional policy - pro-health, pro-family and pro-environmental, infrastructure), their accessibility, quality and efficiency of their use.

The creators of potential of regions are: entrepreneurs, groups connecting the various environmental groups (clusters, associations), Special Economic Zones and innovation.

\section{The entrepreneurs}

The role of entrepreneurs in the region is very high. They create new and varied jobs, unique products, the people of region show their creativity and innovation (Szymańska, 2012, p. 42-54). The development of entrepreneurship contributes to reducing unemployment, creating infrastructure and cooperative service for incoming foreign investment getting them to influx of new technologies and methods. The entrepreneurs also are actively involved in process of changing 
industrial structure of the region through creating production areas and services (Piasecki, 2001, p. 79).

Indicator of the economic activity of the region's population is the number of economic entities per capita. It is one of the most commonly used indicators for measuring disparities in economic development of community. But this is not a perfect indicator because it contains information on all registered entities - including those that do not have activity or it is not completed and checked out of the base (Dziemianowicz,Łukomska, Górska and Pawluczuk, 2009, p. 14).

\section{The clusters}

Changes taking place in the world (social, economic, technological) are a great challenge for market operators (Szymańska, 2013, p. 222). With the advance of globalization, maintaining the international competitiveness of the economy becomes more and more challenging. A new way of creating competitiveness of enterprises and regions is the concept of clusters (The Ministry of Economy, 2009, p. 1).

According to M. Porter's cluster is a geographic concentration of interconnected companies, specialized suppliers, companies from other related sectors or industries and economical institutions (e.g. universities, chambers of commerce) (Porter, 1990).

A more detailed definition of the cluster was reported by the Ministry of Economy in the Regulation of 11 December 2006 - [...] This cluster spatial and sectoral concentration entities acting for economic development and innovation, and at least 10 businesses involved in business activities in one or several neighboring regions, competing and cooperating in the same or related industries and associated developed network of formal and informal nature, at least half of the entities within the cluster are entrepreneurs (The Ministry of Economy, 2009, p. 12).

Enterprises operating in clusters are characterized by higher productivity, economic, scientific and research. In the cluster enterprises can achieve higher degree of innovation - the company starting in the cluster have external suppliers and partners. The benefits of cluster activity is the ability to generate higher productivity, innovation and competitiveness (Miszczak, 2010, p. 7).

A cluster or its surroundings can function well as other specialized units that make up the regional innovation system (Maskell, 2001, p. 921-943), such as technology transfer centers, technology incubators, incubators, technological parks and industrial parks (Boekholt and Thuriaux, 1999). 


\section{The association of local}

Opportunities for the development of local communities depend on the ability to self-organize their efforts and the creation of collective action. The condition for local community engagement in the development of the area and use of its resources is to create social and economy capital in the country. Due to the low level of activity and involvement of rural communities in the local structures of particular importance for the development of rural areas have local action groups.

Local Action Group (LAG) is a type of partnership units typically created in rural areas, bringing together representatives of local organizations (public, private and non-government) and inhabitants of the area designated border communities States. Local Action Group implements Local Development Strategies in the area of population from 10 thousand to 150 thousand residents. This condition is, on the one hand - to provide "local« character, on the other hand - to provide adequate capacity for implementation of the Strategy (Fundusze Europejskie, 2012). A very important part of creating a LAG is that least $50 \%$ of its members belonged to the private and non-governmental sector.

Local Action Groups are responsible for creating and implementing a local development strategy for the territory and the spending of grants allocated for these purposes. Among the objectives pursued by the LAG show: prevention of unemployment, promotion/production of local products, social integration, social mobilization, cultural tradition, environment, natural values, development of tourism, entrepreneurship, development of agriculture and agricultural processing (Ministry of Agriculture and Rural Development, 2009, p. 14).

Creating environment conducive entrepreneurship and innovation is the most promising instrument to stimulate local development and building competitive advantage municipalities, cities and counties, but requires shaping appropriate intellectual capital, innovation culture, specialized resources and expertise. Therefore, this environment has taken various measures to maintain a high growth region. One such measure is the establishment and maintenance of Special Economic Zones.

\section{The special economic zones}

The Special Economic Zones (SEZs) are separated administratively Polish areas where investors can pursue economy activity on preferential terms economy activity is regulated by a special, different than the rest of the country rules of taxation, customs duties, foreign exchange law, labor law, social rights, trade union rights, construction law, regulations governing land ownership, facilitated the transfer of profits and capital. 
The purpose of the SEZs is to accelerate the development of regions by attracting new investment and promote the creation of jobs (Ługowska, 2012).

The Special Economic Zones (Tynela, 2010):

- are an instrument to compete for new investment;

- offer a comfortable and safe budget form for the state of public assistance;

- offer modern workplace - in the counties where is SEZs, unemployment is lower, sometimes even by 3 percentage points and GDP by up to $7.5 \%$ higher than in counties without zone;

- observed increased revenues to local budgets;

- stimulate local authorities to arm areas;

- cause the influx of innovative technologies;

- initiate the formation of cluster structures.

In Poland there are 14 SEZs. Their area is almost 16 thousand hectares. Special Economic Zones created more than 186 thousand new jobs. As of the end of the third quarter of 2012, the value of the investments in SEZs from the beginning of their existence was 83 billion 868 million $\mathrm{zl}$, and the number of new jobs created in the SEZ was $186584^{1}$.

The primary objective of creating Special Economic Zones is to attract capital, especially foreign, for economic activation of selected areas (Brezdeń and Spallek, 2008, p. 217). The special economical zones invest most companies from Poland, Germany, the United States, the Netherlands, Japan and Italy (according to the origin of the capital) $)^{2}$.

\section{Innovations}

The essence of the modern concept of constructing the competitive advantages of the region's is the ability to manage potential by using innovation. Innovation is one of the most important factors of economic growth of regions and community. In the modern world the ability to create and adopt innovations is the biggest challenge for regional and national governments, because innovation processes create their current and future economic situation (Szymańska, 2012, p. 324-326).

Innovation of the region is defined as "the ability of the region to change, improve, reform and innovate in various fields of economic and social life [...] in order to improve the functioning of mechanisms to support development in the region." (Przygocki, 2007, p. 144) Innovative region consists of: research potential, the level of human and social capital (education, matching education to the needs of the region), entrepreneurship and innovation, public authorities (own and

Source: www.premier.gov.pl (2013)

Source: www.premier.gov.pl (2013) 
foreign), innovation of enterprises operating in the region, the development of the business and international environment (A broad-based innovation strategy for the EU, 2009).

Innovative commune is able to use the effects of the environment to increase the potential in an economic and ecological way (Donnelly, Gibson and Ivancevich, 1990, p. 27). Surroundings of innovative region are a set of institutions such as business incubators, centers for the promotion and development of innovation, technology parks, technology transfer centers, networks and relationships that bind them. A well-organized innovative surroundings commune stimulates local entrepreneurship, enables the transfer of technology and allows companies to support projects at any stage of development - from idea, through incubation, support in the development and exit the market (Okon-Horodyńska and Zachorowska-Mazurkiewicz, 2007, p. 7).

\section{Conclusion}

The aim of the article was to characterize the creators region potential (mainly entrepreneurs, clusters, associations, Special Economic Zones) and the relationships between them.

The paper shows that differences in the level of socio-economic development of regions are inevitable, but appropriate use of potential of the region (businesses, community groups, clusters, Special Economic Zones and innovation) will increase the value of the region on a national and European level. This will improve the ability of quick introduction of modern technological solutions dependent on the knowledge, the skills of workers and entrepreneurs, which will form the basis for the economic success of regions and strengthen their position in the country and abroad. Competitive regions will attract capital for further development (domestic and foreign investments), stop owned factors of production, workers and residents. The high value of the region will be demonstrated by the ability to adapt to changes in the economy, technology and society.

\section{Literature}

- Boekholt, P. and Thuriaux B. (1999). Public policies to facilitate clusters: background, rationale and policy practicies in international perspective. [in:] OECD. Boosting Innovation: The Cluster Approach. OECD. Paris.

- Brezdeń, P. and Spallek, W. (2008). Special economic zones in economic space for example voivodship dolnoślaskiego. Prace Komisji Geografii Przemysłu, (10). Warszawa-Kraków. 
- Donnelly, J.H., Gibson, J.L. and Ivancevich, J.M. (1990). Fundamentals of Management. BPI \& RWN. Boston.

- Dziemianowicz, W., Łukomska, J., Górska, A. andPawluczuk, M. (2009). Development trends in regions. Geoprofit. Warsaw.

- Jabłoński, A. and Jabłoński, M. (2012). Value management of the region through the development and growth of small and medium-sized enterprises. Forecast of development of SMEs in the context of the labor market. Grupa MARIS. Katowice.

- Jewtuchowicz, A. (2005). Territory and contemporary dilemmas of development. Wydawnictwo Uniwersytetu Łódzkiego. Łódź.

- Ługowska, K. (30.01.2012). Special economic zones. Retrivered from http:// www.mg.gov.pl/Wspieranie+przedsiebiorczosci/Wsparcie+finansowe+i+inwestycje/ Specjalne+strefy+ekonomiczne.

- Maskell, P. (2001). Towards a knowledge-based theory of the geographical cluster. Industrial and Corporate Change, (10).

- Ministry of Economy, Department of Economic Development (2009). The directions of development of clusters in Poland. Warsaw.

- Ministry of Agriculture and Rural Development (2009). Axis IV of the RDP 2007 - 2013 - Local Action Groups and Local Development Strategies. Warsaw.

- Miszczak, K. (2010). The role of clusters in the development of innovation and competitiveness of Polish regions. Retrivered from https://depot.ceon. $\mathrm{pl} /$ bitstream/handle/123456789/691/Rola\%20klastr\%C3\%B3w\%20w\%20rozwoju\%20 innowacyjno\%C5\%9Bci\%20i\%20konkurencyjno\%C5\%9Bci\%20polskich $\% 20$ region\%C3\%B3w_1.pdf?sequence=1.

- Okoń-Horodyńska, E. and Zachorowska-Mazurkiewicz, A. (red.) (2007). Innovations in the development of the economy and businesses: driving forces and barriers. Instytut Wiedzy i Innowacji. Warsaw.

- Piasecki, B. (red.) (2001). Economics and small business management. PWN. Warsaw - Łódź.

- Porter, M. (1990). The Competitive Advantage of Nations. Macmillan. London.

- Przygocki, Z. (2007). Competitiveness of regions [in] region and its development in the context of globalization. Chądzyński, J., Nowakowska, A., Przygodzki, Z. and CeDeWu Wydawnictwa Fachowe. Warsaw.

- Putting knowledge into practice: A broad-based innovation strategy for the EU. (30.09.2013). Retrivered from http://register.consilium.europa.eu/pdf/ pI/06/stI2/st12940.p106.pdf.

- Specjalne strefy ekonomiczne (SSE) w liczbach. Retrivered 17.10.2013 from https://www.premier.gov.pl/specjalne-strefy-ekonomiczne-sse-w-liczbach.html.

- Status of implementation of the Rural Development Programme 20072013 (2012). European Funds, (4). 
- Szymańska, K. (2012). Innovation communities and regions, Перспективы Инновационного Развития Республики Беларусь, Сборник научных статей, (red.) Боровикова Е. А., Брестский государственный Технический Үниверситет, Брест2012.

- Szymańska, K. (2012). The economic crisis and the sector of small and medium-sized enterprises [in] Contemporary challenges businesses and regions and the economic crisis. E. Gąsiorowska, L. Borowiec, M. Burżacka (red.); Wydawnictwo PWSZ Ciechanów 2012 r.

- Szymańska, K. (2013). Organic Food Cluster Answer to the Problems of Food in the World. [w:] Challenges of the Modern World. Novosibirsk State Uniwersity of Economics and Management. Novosibirsk.

- Tynela, P. (2010). Special Economic Zones after 2020. Analysis of current activities and prospects of their functioning. Raport EY. Warsaw.

Paper received: May $15^{\text {th }}, 2014$

Approved for publication: June $1^{\text {st }}, 2014$
Rad primljen: 15. maj 2014. Odobren za štampu: 1. jun 2014. 
Dr Katarzyna Szymańska,

Fakultet za inženjering i ekonomiju, Poljska

\section{FAKTORI KOJI OBLIKUJU KONKURENCIJU U REGIONU}

\section{S a ž e t a k}

Regioni se međusobno takmiče za najvišu poziciju u zemlji. Postizanje i zadržavanje tog mesta je povezano sa prednostima kao što su privlačenje investitora, rast preduzetništva, poboljšanje stambenih uslova, niža nezaposlenost, manji socijalni izdaci, razvoj tržišta nekretnina, kao i lokalno bogaćenje.

Pokretači regionalnog potencijala su: preduzetnici, grupe koje povezuju razne subjekte (klasteri, udruženja), specijalne privredne zone, znanje, inovacije i uslovi za život stanovništva.

Regioni se međusobno takmiče koristeći spomenike, privlačeći investitore i investirajući kapital. Glavni fokus teritorijalne konkurencije je povezan sa kolalnim dobrima. Najčešći i najopštiji faktori u teritorijalnom takmičenju su unutrašnji i spoljni. Spoljni faktori se sastoje od nacionalne i globalne sredine, društvenih i ekonomskih potreba, kao i od politike prostornog planiranja države i drugih organizacija. Unutrašnji faktori su lokalne mogućnosti i potrebe razvoja. Oni se nalaze u sistemu lokalne koordinacije i zavise od lokalnih sredstava (količine i kvaliteta obrazovanja stanovništva regiona, prirodnih bogatstava regiona, kao i od politike regiona; da li podržavaju zdravstvo, porodicu, životnu sredinu i infrastrukturu), kao i od njihove dostupnosti, kvaliteta i efikasnosti upotrebe.

Cilj ovog rada je da se razgovara o pokretačima regionalnog potencijala (mahom preduzetnika, klasterima, udruženjima, specijanim ekonomskim zonama), i odnosa između njih.

Ključne reči: skupine, lokalne asocijacije, specijalne ekonomske zone, razvoj regiona 
